\section{The effect of English as a Second Language (ESL) Teacher Talk in Creating Classroom Interactions}

\author{
Jayalath, U.D.T.L. ${ }^{1, *}$ \\ ${ }^{1}$ Department of English Language Teaching, University of Kelaniya, Kelaniya, 11600, Sri Lanka.
}

Received: 29 November, 2020, Revised: 09 April, 2021, Accepted: 27 June, 2021.

How to Cite this Article: Jayalath, U.D.T.L. (2021). The effect of English as a Second Language (ESL) teacher talk in creating classroom interactions. Sri Lanka Journal of Social Sciences and Humanities, 1(2), 181-191.

Sri Lanka Journal of Social Sciences and Humanities Volume 1 Issue 2, August 2021: 181-191 ISSN: 2773 692X (Online), 27736911 (Print) Copyright: (C) 2021 The Author(s)

Published by Faculty of Social Sciences and Languages, Sabaragamuwa University of Sri Lanka Website: https://www.sab.ac.lk/sljssh DOI: http://doi.org/10.4038/sljssh.v1i2.49

\begin{abstract}
The success of teaching and learning depends on the way the teacher talk and the interactions that occur between teachers and students. The use of teacher talk can be considered a necessary as well as an unnecessary source in generating interactions. The study entitled 'The effect of ESL Teacher Talk in creating classroom interaction' has the objectives to portray the effect of ESL teacher talk in creating classroom interactions. This research employed an observation sheet, questionnaire and audio recording to reach the objectives. The categories of teacher talk existed in the classroom were discovered by using the observation sheet. Thereby, asking questions and lecturing were found as the dominant ones. The questionnaire was used to gain the students' perceptions that supported the findings of the effects of teacher talk in which students perceived that the teacher indirectly asks many questions to involve them in the interactions. Thus, the study implies the idea that the teacher plays a major role in the classroom using the language to guide various types of functions as questioning, eliciting, explaining, giving feedback and instructions to generate interactions throughout the lesson. It is suggested that teachers should pay attention to their language in the process of interactions with the students to provoke more interactions in the classroom.
\end{abstract}

Keywords: Classroom interactions, English as a Second Language (ESL), Second Language Acquisition (SLA), Teacher talk

\section{INTRODUCTION}

The present study on the language used in classroom interaction by an ESL (English as a second language) teacher portrays how the language of the teacher plays a significant role in the teaching and learning process. Gebhard (2006) defines a teacher's language as the language which is used by the teacher to conduct the teaching process in the classroom. The classroom is the best place for language learners to be fluent in that language. Therefore, the language of the teacher becomes an essential and influential feature, especially in a language classroom. In this study, the terminology, 'teacher talk' is used to refer to the language used by the teacher in an ESL classroom. Interaction defines the idea of collaborative exchanging of thoughts, feelings, or ideas between two or more people (Brown, 2006). In the present study, the researcher has focused on how the language of the teacher becomes effective in handling classroom interactions. Therefore, the roles that a language teacher plays are as a facilitator, diagnostician, monitor, assessor and language resource and rapport builder.

The importance of the language used by the teacher presents through classroom observation. It highlights the fact that the success of teaching depends on the way the teacher uses the language to interact with the students. The present study conveys how the teacher uses the language to explain, review, elicit, support, encourage, give advice, instructions and feedback, and ask questions. Further, when considering the use of mother tongue the previous studies (Brown, 2001, ZhouXing \& Zhou Yun, 2002, Nunan, 1991, Allwright \&
Bailey, 1991) emphasized that the use of the first language as a controversial feature as to use or not to use in ESL teaching context. However, the observed teacher tried her best to minimize the use of the first language but most of the students were highly expected it in teacher talk for better understanding. However, the teacher addressed all different levels of the students as a speech community that were from various social backgrounds through the teachers' effective way of using the language.

The objectives of this study are presented as the following, to,

- investigate how teacher talk affects the classroom interaction.

- understand the language of the teacher mainly in asking questions, giving instructions and giving feedback.

- analyze teacher talk with Austin's speech act theory.

- highlight the use of code-mixing and switching in teacher talk and to elicit the use of power and solidarity in teacher talk.

- analyze the impact of the language used by the teacher upon the students' second language acquisition.

To achieve the above-mentioned objectives, the researcher has gone through the studies conducted over the periods of the last three decades. There were studies on teacher talk and characteristics of classroom interactions in ESL classroom. The gap of this research is with the previous research

\footnotetext{
* Corresponding author: Tel.: +94 (717048406) ; Email: thisu11223jayalath@gmail.com

(iD) https://orcid.org/0000-0001-9700-6254
} 
is the current study focuses on the effect of teacher talk in creating interactions in ESL classroom. Thereby, the researcher conducted the present study answering the following questions,

- What are the functions of teacher talk in the ESL classroom?

- How does the teacher talk affect in classroom interaction?

- How does the use of L1 in teacher talk affect the learners' learning?

- What are the learners' perspective toward teacher talk?

\section{LITERATURE REVIEW}

The study of teacher talk in the area of second language acquisition has been commenced during the past twenty years, pioneering the studies of Gaie $(1977,1979)$ and Henzle (1979). Later, in recent years, the research on the same field has been developed by scholars like Ellis and Barkhuizen (2005), and Berlin (2005) focus on features of teachers' talk.

Teacher Talk: Teacher talk plays a vital role in the language classroom as a tool of implementing teaching plans and achieving teaching goals (Incecay, 2010). Thus, teacher talk is an important input for the learners and it becomes an essential feature in classroom interaction (Putri, 2015). As Nunan (1991) emphasized teacher talk is highly significant in both organizing the classroom and conducting the process of language teaching, stating "Teacher Talk is of crucial importance not only for the organization of the classroom but also for the process of acquisition" (Nuna, 1991). The type of teacher talk is also regarded as a decisive factor of success or failure in classroom teaching (ZhouXing \& Zhou Yun, 2002). Also, in the classroom, teacher talk plays an essential role. Teacher talk has a deep impact on the classroom interaction that occurs with students. Yanfen and Yuqin (2010) denote that appropriate teacher talk could create a positive atmosphere in the classroom and make a friendly relationship between teacher and student. Further, Allwright and Bailey (1991) mentioned that talk is a "worthy way that the language teacher uses to deliver information and control the learning behaviour of students" (Allwright \& Bailey,1991, p.139). Thus, classroom interactions become the result of the teacher talk. Abhharan's (1997) suggestion also implies that the patterns of classroom interactions occur due to the teacher talk and the development process of thinking skills. Moreover, Yanten and Yuqin (2010) indicate that teacher talk is also believed as a source to provide more opportunities for students to interact in the classroom. When considering the patterns of classroom interactions, it is highlighted that interactions are correlated to the teacher talk and the development process of thinking skills (Abhharoon, 2013).

According to Flanders' Interaction Analysis Categories (FIAC), teacher talk presents in two ways, as the direct and indirect influence. He refers to direct influence to the acts of lecturing, giving instructions, and criticizing; the indirect influence is to ask questions and to praise or encourage students.

Features of Teacher Talk: Most of the studies on teacher talk mainly focus on the features or the characteristics of teacher talk. Thus, Xuewen (2003) discussed the speed, pause, and repetition, modification of teacher talk as the forms of teacher talk while Weidong and Ming (1998) pre- sented the quality and the quantity of teacher talk, the questions that the teachers use, interactional modifications and feedback as the features of teacher talk.

\section{Functional features of Teacher Talk}

The amount of Teacher Talk: In language classrooms, both the teachers and students participate actively. As Xiao-yan (2006) stated teachers have to face two tasks in language classrooms as to offer enough high-quality English language input and also to offer more opportunities for students to use the target language in the classroom. Thereby, the distribution of teacher talk time is important in teaching and generating classroom interaction since the amount of teacher talk influences learners' L2 acquisition. Studies have found that teachers tend to do most of the classroom talk. According to Cook (2000), teacher talk makes up over 70 per cent of the total talk in the classroom. However, it is evident that if the teacher devotes a large amount of time to lecturing and explaining the lessons, students will be indeed severely had fewer opportunities to interact. Therefore, to avoid the over-use of Teacher Talk, many scholars (Xiaohong, 1998 \& Xing \& Yun, 2002) tend to maximize Student Talk Time (STT) and minimize Teacher Talk Time (TTT). Thereby, Harmer (2000) conveys that the best lessons are ones in which Student Talk Time is maximized and Harmer (2000) further states that a vital part of the teacher's role is to get the students to speak in the language classroom.

Teachers' questions: The use of questions is one of the main features of the teachers' talk (Richards \& Lockhart, 2000). Further, it can be considered as an approach to conduct classroom interaction in second language acquisition. According to Richards and Lockhart (2000), questioning is one of the most common techniques used by teachers. They further denoted that in some classes the half of the class time is taken up by asking questions and answers. Thus, it is explicit that questioning in teacher talk may become a principle in generating interactions. It is significant in a language classroom to make the students active and fluent in communicative proficiency.

Questioning in teacher talk provides opportunities for students to speak in English during the lesson. Brown (1994) stated that speaking is an interactive process of building meaning that includes producing, receiving, and processing information.

According to scholars (Donald, K. \& Eggen, P. D, 1989 \& Richards \& Lockhart, 2000), the questions in the classroom can be analyzed with the specific functions they perform. Thus, Donald, K. \& Eggen, P. D (1989) grouped the functions of questions as diagnostic, instructional and motivational questions. Moreover, Richard and Lockhart (2000) also analyzed the questions in teacher talk as procedural, convergent and divergent questions.

Teachers' instructions: As Wicaksono (2006) stated giving directions or instructions is the teacher's way to direct, request and give a command to the students and it usually expects the students to do or follow the instruction. Further, Xiao-yan (2012) defines teacher talk as the kind of language used by the teacher for instruction in the classroom. Thereby, instruction-giving has a direct effect on learning; as Scrivener (2011) implied instructions and their delivery can be the determining factors as to whether a lesson succeeds or fails. In addition, according to Ur's $(1996$, p. 16) study indicates "that learners see the ability to explain things well as one of the most important qualities of a good teacher". Thus, Sowell (2017) also considered instruction-giving as an essential part of an effective lesson and an important part of 
classroom management as well as in generating classroom interaction.

Teachers' feedback: Giving feedback can be highlighted as one of the main elements in teacher talk, especially in an ESL classroom (Xiao-yan, 2012). As Cook (2000) defined, feedback is teachers' evaluation of the students' responses. The purposes of giving feedback are to motivate the learners, to encourage the learners' autonomy, and to help learners to understand their problems in using the second language and how they can minimize those issues. According to Richard and Lockhart (2000), feedback means to praise, by any relevant comment or action or by silence even.

Further, Xiao-yan (2012) stated that teachers' feedback plays a significant part in an individual's motivation as it allows the children to learn how 'smart' they were in their performances (Weinsein, 1989). Thereby, as Ur (2000) analyzed feedback has two main distinguishable components as correction and assessment.

\section{Classroom interaction and Second Language acquisition}

As Richards \& Lockhart (2000) identified second language learning is a highly interactive process. Further, scholars as Allwright (1984), Ellis (1990), Long (1983) and Swain (1985) revealed the importance of classroom interaction in language acquisition as the interaction involves both input and output of learning. Thus, when considering the Interactional Hypothesis (Long, 1983, 1996), it conveys that acquisition occurs through the process of interaction as the learners acquire through interacting with others in the classroom (Johnson, 2002). In addition, Allwright (1984) and Ellis (1990) also emphasized that classroom teaching should be treated as interaction and highlighted the importance of interaction in language learning.

Moreover, Lier (1988) also conveyed the importance of interaction in language learning highlighting the input and meaningful interaction. As Lier (1988) pointed out the interaction mediates between input and intake as following,

Figure 1: The role of interaction (Lier, 1983)

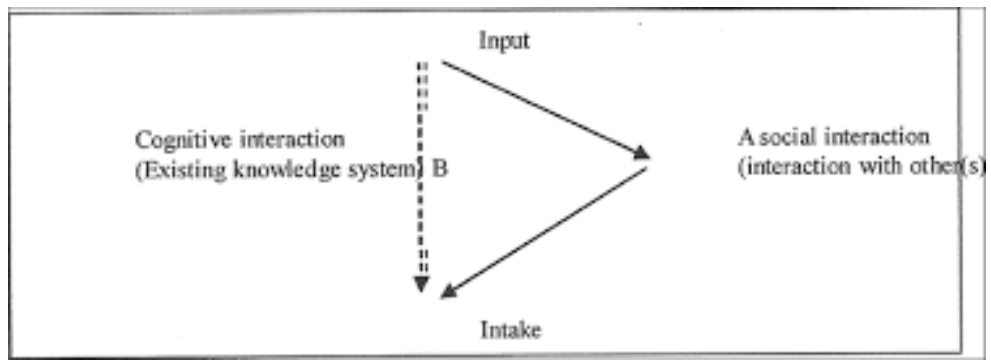

\section{Austin's Speech Act Theory}

Austin's (1962) Speech Act Theory revealed that the action performed when an utterance is produced can be analyzed on three different levels as locutionary act, illocutionary act and perlocutionary act. Locutionary act refers to the basic act of utterance or producing a meaningful linguistic expression while illocutionary act refers to the real actions which are performed the utterance. Further, perlocutionary act is the effect produced on the hearer's reaction and while illocutionary is the speaker's motivation. (Yi-xuan, 2016).

When considering the speech acts highlighted in the theory, Austin (1962) focused mainly on two types of utterances as constative utterances and performative utterances. Thus, constative utterances describe or report something either true or false while performative utterances refer to when a speaker may do something by acting.

\section{MATERIALS \& METHODS}

The researcher followed the method of a case study to capture the real phenomenon of the language used by an ESL teacher in classroom interaction. Stenhouse (1990) emphasizes the task of a case study is to produce reports of experience and offer evidence, not to deal with generalization. Further, Zainal (2007) also indicates that the case study analyzes data from a small number of individuals as the main subjects. Thus, the classroom represents a particular social unit, as well as the researcher, depicted the main aspects of this unit as teacher talk and interaction through an intensive study.

The study was mainly based on primary data. It was conducted through direct participation; the classroom observation was conducted. Thus, the research was conducted in an
ESL classroom of one of the tuition classes in Gampaha district which involved an experienced teacher and twelve students in grade seven.

\section{Participants}

Teacher: The surveyed teacher is Sinhalese with five years of experience in ESL teaching. The teacher completed Bachelor of Arts in English at University of Sri Jayawardenapura and Masters of Arts in Linguistics at University of Kelaniya. In addition, the teacher is qualified with CELTA (Certificate in Teaching English to Speakers of Other Languages), Cambridge ESOL.

Students: The participated students in the current study are Sinhalese aged between 12 and 13. They had studied English for 3 years in primary school and one year in secondary school. The language proficiency levels of the students are different.

\section{Research methods and instruments}

As the purpose of the present study is to find out the effect of teacher talk in generating interactions in an ESL classroom setting, the methods like a case study of the teacher and an investigation among students were utilized. Thereby, the research is naturalistic, as Allwright and Bailey (1991) emphasized 'naturalistic inquiring' is adopted as a research method to investigate what is going on in the language classroom. Further, in this research, the researcher applied the qualitative research method as the researcher's observation included a detailed explanation of what the teacher talk and its effects were about. The observation of teacher talk in the selected ESL classroom was further analyzed according to related theories and studies. Thereby, the detailed opinions and in-depth explanations of the research give it a qualitative nature. 
The data collection instruments include classroom observation and tape-recording and questionnaire. During the classroom observation, the researcher observed the teaching sequence and the teacher's performance in the classroom is recorded completely naturally. Thus, the gathered data in the study are representative of the normal practices of teaching. In addition, for the study, a questionnaire is prepared for the students. Thereby, these two research tools can be studied correlatively to get a thorough understanding of the teacher talk and its effect in creating interactions in an ESL classroom.

\section{Classroom observation and classroom tape-recording}

The researcher participated for only one period of a teaching session to enhance the validity and reliability of the research. Here, the researcher prepared an observation sheet to collect the actual data in observing the teacher talk and its effect on classroom interactions. The whole process of teaching was tape-recorded to present what happened in the classroom when the teacher talk was going on. A thirty minutes lesson was tape-recorded from a two-hour class and a detailed transcription of the record was worked out because the researcher aims to focus on the teacher's language in classroom interaction.

The observed lesson was a reading lesson to focus on the reading skills and to improve the writing ability to answer comprehension questions. There, initially, the teacher activated the schemata to the lesson by setting the context to the lesson. Thus, the teacher asked questions relating to their prior knowledge on the subject (boat riding) of the lesson and discussed the students' experiences to visualize the scene. Then, the teacher did the pre-teaching lexis session to get the learners ready for the new words by providing a worksheet to do individually and discussed the answers with the class. After that, the students read the story by taking turns and the teacher elicited the story by asking questions. Then, the comprehension questions were given and answers were discussed while the teacher was giving feedback for the whole class.

\section{Questionnaire}

A questionnaire with five items was given to the students to gain their perception of teacher talk in language learning. Thus, the questionnaire is used as a subsidiary research instrument to capture individual's preference towards teacher talk and their evaluation about the teacher's talk. Further the questionnaire was used to investigate how the teacher influenced the students indirectly by asking questions to involve them in the interaction.

\section{RESEARCH DISCUSSION}

\section{Data Collection}

The researcher used an observation criteria sheet to capture features and functions of teacher talk in classroom interaction. It consists of the following the features of the teacher talk.

The language used by the teacher,

- To greet students.

- To review the previous model of the lesson.

- To support the students' answers being a facilitator.

- To introduce the new material of the lesson.

- To explain any topic.

- To give instructions.

- To encourage and motivate students.

- To convey the meaning of the words.
- To give feedback.

- To give advice.

- To monitor the class when students engaged in activities.

- To close the class.

Moreover, the recorded data were collected according to the research questions of the study. Thereby, the analysis of the data highlighted that the teacher uses the language to ask questions and to give feedback and instruction as the main functions of the teacher talk.

\section{Major findings and Data Collection}

\section{Major findings in Teacher Talk.}

The analysis of the data highlighted that the teacher uses the language to ask questions and to give feedback and instruction as the main functions of the teacher talk. Throughout the analysis, the researcher presented the examples that have been taken from the transcription of the observed teacher talk.

Teacher's questions: The use of questions is one of the main features of the teacher's talk. Further, it can be considered as approach to conduct classroom interaction in second language acquisition. According to Richard's and Lockhart's (2000), questioning is one of the most common techniques used by teachers. They further denoted that in some classes the half of the class time is taken up by asking questions and answers. Thus, it is explicit that questioning in teacher talk may become a principle in generating interactions. It is significant in a language classroom to make the students active and fluent in communicative proficiency.

Questioning in teacher talk provides opportunities for students to speak in English during the lesson. Brown (1994) stated that speaking is an interactive process of building meaning that includes producing, receiving, and processing information

According to the present study, the teacher used questions throughout the lesson in several ways as mentioned below,

To introduce the lesson.

\section{T: Have you ever travelled by a boat? \\ Have you ever seen a boat riding? Atleast in a cartoon or} in a film, have you ever seen a boat riding?

As mentioned in the example, the teacher asked questions initially to activate the learners' motivation and interest as the basic stage of the lesson. Thus, by asking questions the teacher arouses the prior and background knowledge of the learners before starting the lesson. As setting the scene for the lesson the teacher conducts a mini discussion by asking questions to activate learners' schemata as well as to introduce the topic of the lesson.

To elicit the lesson by using concept checking questions.

T: Who else in the ship? Then? Yes... Fish are there,

In the sea what else that you can see?

Okay, what else?

It may be a sunny day or what else? Windy?

The observed teacher talk reveals that the teacher asks questions to elicit the lesson (as in the afore-mentioned extract). As emphasized here, the teacher mostly uses concept checking questions to ensure the comprehension of the target language and to raise the awareness of its problems. Hereby, it helps the teacher to check the understanding of the difficult aspects of the target structure in terms of function and meaning. Throughout the surveyed lesson the 
teacher elicits the lesson by asking questions while indicating whether the students have fully understood or not.

To support students to speak.

T: Very good, In the sea, yes, it is correct; then tell me normally, who are there?

According to the above extract, it conveys that how the surveyed teacher asked questions to support the learners to speak or to present their answers. Further, it highlights that teacher talk makes the learners feel confident and motivated when they are talking in the classroom and also it helps them to present the most accurate and relevant answer.

To build up a good rapport among students.

T: How was your vacation? Was it good?

S1: Yes teacher.

T: Great! What about others? How did you spend your vacation?

The aforementioned extract portrays that the teacher asked questions to build up a good rapport in the classroom by asking questions. Here, the teacher fostered a warm, positive environment where the students are motivated to attend the class and participate in discussions. As highlighted in the example, the teacher allowed students to talk about what they did on their vacation. Thus, it allows time to chat informally with the students as a casual conversation to garner rapport because the rapport between the teacher and the students can be considered as a significant factor in the overall learning and success of individual students. Further, Dyrenforth (2014) stated the rapport improves numerous classroom areas as motivation, feedback, student learning, communication, and not to be ignored.

\section{To give instructions}

$\mathrm{T}$ : Then, how many sentences are there?

SS: Ten

T: Yes... Ten, very good...Then, how many words are there?

SS: twelve

$\mathrm{T}$ : Okay...then how many extra words?

SS: Three

As highlighted in the extract, the teacher asked questions when giving instructions to consider whether the students have understood the given instructions; because without instructions, the students may become confused, may lose confidence and may not achieve the target language properly. Thus, after giving instructions the teacher asked questions to determine if the students understood without asking, 'do you understand now?'.

Mainly the teacher had used open and closed questions in different functions of the lesson. The teacher asked concept checking questions and instruction checking questions to check the level of understanding of the students.

When considering the several notions of scholars, the questions used by the teachers are different. According to Donald and Paul (1989), there are three types of questions used by ESL teachers.

\section{1) Diagnostic questions.}

The teachers use this type of questions to diagnose the gaps in the knowledge of students. It allows the teacher to get to know whether the students have understood the lesson or not. The present study also exemplifies that the teacher asked this type of question. At the beginning of the lesson, the teacher used this type of question to review the previous lesson. Further, after teaching the lesson she asked diagnostic questions in several ways to glimpse into the minds of students to check their intelligibility without asking 'do you understand the lesson?' here, the questions that she asked can be exemplified as follows,

$\mathrm{T}$ : Who are there? There are three names mentioned?

$\mathrm{T}$ : Where do they live? With whom?

\section{2) Instructional questions.}

This is the second type that Donald and Paul (1989) have cited. The teachers use this type of questions to help the students to learn new materials and integrate their knowledge and to instruct the students as the follows,

$\mathrm{T}$ : then, how many sentences are there?

$\mathrm{T}$ : Then, how many words are there?

3) Motivational questions.

The teachers use these questions to encourage students to communicate. It makes the students' communicative proficiency of the students by motivating them to speak in the class. Further, it provides opportunities to generate classroom interaction patterns. The examples are,

$\mathrm{T}$ : Why? What is your problem? Are you okay?

T: yes what is the problem Anuhas? Okay? Don't worry about the meaning. You don't need to know all this meanings of these words just try to find the answer.

Moreover, Richard and Lockhart (2000) also analyzed the questions used in the language of the teacher as follows,

- Procedural questions.

- Convergent questions.

- Divergent questions.

Here, procedural questions are quite similar to the above discussed diagnostic questions. The teachers use this type of questions to ensure the smooth flow of the teaching process. Thus, the teacher could get an idea about the students' understanding of the lesson. Next, they use the convergent and divergent questions to engage the students in the context of the lesson. These questions allow the teachers to facilitate the comprehension knowledge of the students. The functions of these types of questions are similar but according to the answers that the teacher expects, these two become distinct. Convergent questions are always requiring a short answer as mentioned below,

\section{$\mathrm{T}$ : What are the key words that you can find?}

\section{S: - a large, water bird}

\section{T: - it is talking about the large water bird, what else? \\ S: - lion}

Here, the teacher did not expect a high level of thinking from the students but the teacher just wanted to promote classroom interactions by providing chances for students to engage in the lesson. On the other hand, when considering the above-mentioned examples it is clear that the teacher's expectation was different because the responses are long which requires a high level of thinking, thus, the teachers let the students provide their information to enhance fluency and accuracy in students' speeches.

Teacher's instructions: The function of giving instructions has a direct effect on students' learning. It is because a lesson or activity becomes chaotic or fails when students do not understand what they are supposed to do. Thus, instructions in teacher talk should be simple and explicit for the students to understand easily. And instructions in teacher talk should also deliver along with pauses. Many scholars have 
denoted the idea that giving instruction is a function that warrants the use of L1 in the L2 classroom.

When observing the teacher's function of giving instructions, the teacher tried to get the attention of the students first by saying, "listen!". Scrivener (2012) stated if students are not listening to the teacher the quality of the direction is irrelevant. Then the teacher used simple utterances to instruct. Here, the purpose of using English in the classroom enhanced students' capability to reach the expected level of proficiency for a skill or process. However, the teacher could be able to understand the fact that students did not get the ideas what they have to do in the particular activity. Therefore, the teacher used instruction checking questions (ICQs) and $\mathrm{L} 1$ to provide a better understanding as follows,

$$
\begin{aligned}
& \text { T: - then, how many sentences are there? } \\
& \text { SS: - ten } \\
& \text { T: - ten, very good! Then, how many words are there? } \\
& \text { SS: - twelve } \\
& \text { T: - then how many extra words? } \\
& \text { SS: - two }
\end{aligned}
$$

Thus, the present study shows that the teacher asked questions to check the understanding of the students before providing the worksheets.

Teacher's feedback: Giving feedback can be highlighted as one of the main elements in teacher talk, especially in an ESL classroom (Xiao-yan, 2012). As Cook (2000) defined, feedback is teachers' evaluation of the students' responses. The purposes of giving feedback are to motivate the learners, to encourage the learners' autonomy, and to help learners to understand their problems in using the second language and how they can minimize those issues. According to Richard and Lockhart (2000), feedback means to praise, by any relevant comment or action or by silence even.

Here, the ESL teacher that the researcher observed used two types of giving feedback as immediate and delayed. As Ur (2000) stated, the feedback has two main components. Those are,

- Correction.

- Assessment.

1) Correction.

When observing the error correction in teacher talk in the present study the used several techniques such as,

- Direct error correction

- Prompting

- Repairing

These ways of error correction in teacher talk supported the students to clarify their understanding of that specific item of the language.

\section{a) Direct error correction.}

This method is very open and direct and it is less time-consuming when correcting. It makes the students avoid mistakes. The following are the examples,

T: Have you ever hear about the word pirate? Who is the
pilot? Who is the pirate? Pirate!
S: - Captain
T: - oh! Not in a plane, not a captain,

\section{b) Prompting}

This is a general way of correcting errors because the researcher could be able to find that the use of prompting in teacher talk generated many interaction patterns and it encourages the students to speak. The teacher always prompted the students to recall the information instead of just telling the answer. In that case, it is evident that the teacher gave the fullest opportunities for the students to speak. The examples in the present study are,

$\mathrm{T}$ : - a land which is situated in a rural area, what does it mean rural? What is the opposite word of rural? Rural iscsip

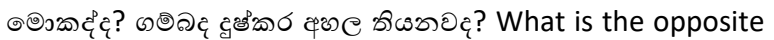

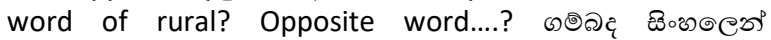

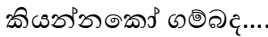

S: - ऊைరอदุ

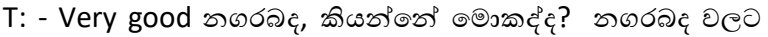

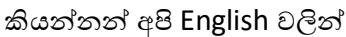

Ur .... U.R.B.A.N...?

\section{C) Repairing}

This is a common feature in the teacher talk in an ESL classroom. It is because when communicating the language students do a lot of mistakes as language learners. In the present study, the teacher intervened and provided the missing language to support the students; answers. It was very effective in students' second language acquisition because it made the students to be motivated in second language acquisition. Sometimes the teacher used the speakers' first language and highlighted the keywords.

S: Their father taught them to sail when they were very
young
T: - when they were very young
S: - Hugo and Charlie b...
T: - Brilliant! Their father taught them to sail when they were
very young
T: - when they were very young
S: - Hugo and Charlie b...
T: - Brilliant

\section{Teacher's assessment}

The teacher's assessment is a significant feature in giving feedback. Here, the teacher informed the students how well or badly they performed. When the teacher used assessment in teacher talk, she found it as a chance to help and encourage ESL learning in all students. It let the students be active in the lesson. The assessment can be discussed in ways in teacher talk when giving feedback.

- Confirmation

- Encouragement

1) Confirmation.

The teacher used confirmation when a student gave a correct answer. Thus, the teacher said,

T: - Okay, why, why did the others use the nick names for Charlott?

S: because all his nick names are shorter okay,

T: very good.

Sometimes the teacher used confirmation to remark the incorrect answers in a positive manner, saying,
$\mathrm{T}$ : Then who needed more practice?
S: - Charlie
T: - No... Who needed more practice? (In a high voice) S: - Jack

\section{Encouragement}

In the currents study, the teacher used encouragement when she gave a feedback to a wrong answer. The use of encouragement did not make the child to be inferior, but it 
encouraged him or her to be confident to do better in the next time.

T: Then, who were brilliant at sailing?

S: - Jack

S: Hugo and Charlie

T: - Hugo and Charlie not Jack. Be careful!
Major findings in ESL learners' perspectives in Teacher Talk. ESL learners' perspectives towards Teacher Talk in second language acquisition were gained from the questionnaire. The following table reveals the students' perspective towards teacher talk in the classroom.

Table 1: The results of the questionnaire

\begin{tabular}{|c|c|}
\hline \multirow{2}{*}{\multicolumn{2}{|c|}{$\begin{array}{l}\text { The questions } \\
\text { I like when the teacher, }\end{array}$}} \\
\hline & \\
\hline Explains the lesson & 04 \\
\hline Explains the meaning of the words & 01 \\
\hline Asks questions & 04 \\
\hline Gives instructions & 01 \\
\hline Gives feedback & 02 \\
\hline \multicolumn{2}{|l|}{ I like that part (mentioned in Q. 2) because, } \\
\hline She uses English all the time. & 01 \\
\hline She uses Sinhala (L1) all the time. & - \\
\hline She uses both languages (Sinhala \& English) equally. & 06 \\
\hline She allows us to ask any question during the lesson. & 03 \\
\hline She gives us clear instructions & - \\
\hline She gives us comprehensible feedback either good or bad & 02 \\
\hline \multicolumn{2}{|l|}{ I do not like when the teacher, } \\
\hline Explains the lesson. & 01 \\
\hline Explains the meaning of the words. & 04 \\
\hline Asks questions. & 01 \\
\hline Gives instruction. & 04 \\
\hline Gives feedback. & 02 \\
\hline \multicolumn{2}{|l|}{ I do not like that part because, } \\
\hline The teacher uses English all the time & 04 \\
\hline The teacher uses Sinhala all the time. & - \\
\hline The teacher asks too many questions in explaining the meanings. & 04 \\
\hline The teacher repeats the instructions many times. & 03 \\
\hline She does not give a clear feedback. & 01 \\
\hline \multicolumn{2}{|l|}{ A) I like when the teacher uses, } \\
\hline Sinhala (L1) all the time. & 01 \\
\hline English (L2) all the time. & 02 \\
\hline Both languages (Sinhala \& English) equally. & 09 \\
\hline B) Because, & \\
\hline I do not understand when the teacher uses English all the time. & 03 \\
\hline I do not want to learn English using my first language (Sinhala). & 01 \\
\hline I can understand everything when the teacher uses both languages (Sinhala \& English) & 08 \\
\hline
\end{tabular}

According to the results of the questionnaire, the learners',

- Most preferable function in Teacher talk

- Least preferable functions in Teacher talk

- Reasons to be the most and the least functions

- Preferred medium of teacher talk can be found.

- The learners' most preferable function in teacher talk and reasons.

According to the collected data, most of the students like it when the teacher explains the lesson and asks questions and also giving feedback. Thus, it conveys the students are generally expected to participate actively as they prefer to be asked questions. This indicates their strong desire for participation and higher expectation toward the opportunity of speaking English.

Further, as the reasons, the students responded that they like when the teacher uses both L1 and L2/ Target language in teacher talk. In addition, the students like it when the teacher gives them the opportunities to ask questions during the lesson. Thus, it conveys that most of the students in the class desire to have an interactive learning environment in which they can communicate well by asking questions and answering when learning the language. Further, the participated students agree that they like when the teacher gives them feedback because they mentioned that they receive more effective feedback which increases their motivation and encourage them in using the target language.

- The learners' least preferable function in Teacher talk and reasons.

The findings illustrated that the learners do not like when the teacher explains the meaning of the words and gives the instructions. The findings might suggest that the learners like to receive information passively instead of actively listening to the teacher.

Thus, as the reasons, the students conveyed that the teacher asks many questions when explaining the meanings of the words and the teacher repeats the instructions many times. Thereby, the students expect to be independent in finding the meanings of the words as to participate in the lesson. Thus, it shows that a large number of students prefer to find 
the meanings by themselves rather than listening to the teacher.

- The learners' preferred medium of Teacher talk and reasons.

According to the learners' responses, it is conveyed that the learners prefer when the teacher uses both L1 (Sinhala) and L2/ Target Language in teaching. Here, the students selected both languages to be used in teacher talk even one language is mentioned as an option. The students further emphasized that they like when the teacher code switches from L1 to L2 or vice versa during the class both languages as it helps them to understand the target language well and it may fulfil a linguistic need or social or psychological purpose as it helps to minimize their language anxiety in the classroom. Even the use of mother tongue in English language teaching has been a controversial issue for teachers, the findings of the study convey that it becomes an essential factor as the students always expect the use of code-switching in teacher talk to achieve a better understanding in learning the target language.

\section{Discussion}

\section{Teacher Talk according to Austin's Theory (1975)}

When speaking, we make various types of sentences. It may be long or short. However, each sentence indicates the idea of what the sentence does, which is known as the functional approach. Further, Austin's speech act theory emphasizes that the speech is used by an individual not only to present information or just saying something but also to perform actions as a speech acts.

In that theory, Austin (1975) highlighted that there are mainly two types of utterances.

- Constative utterances.

- Performative utterances.

\section{Constative utterances.}

Here, this type of utterances does not denote an action. As Austin says, these constative utterances are used only in descriptions and assertions. Constative utterances describe or report something either true or false. Austin further stated that uttering a constative is 'just' saying something. When considering the findings of the study along with the speech act theory constative utterances are,

$\mathrm{T}$ : It is windy.
$\mathrm{T}$ : It is easy.

\section{Performative utterances}

Performative utterances are different from constative utterances. Austin argues that instead of saying something, a speaker may do something by acting as performative utterances. When referring to the teacher talk, it is explicit that most of the utterances in teacher talk are performative utterances.

According to Austin's theory, the language is more than the function, each utterance should act; for example, when the teacher said 'good morning' it is used not only to greet but also it indicates the idea that the teacher wanted to start the class. Austin discussed implicit and explicit preformatives as two types of preformatives. The implicit performatives highlighted what the speaker has in mind by saying it is not specifically indicated. The speakers use explicit performatives to indicate the speech act involved by inserting the performative verb such as command, order, thank, and, warn and so on before the clause. According to Austin's theory on speech act, there are five categories in performatives. These are verdictives, exercitives, commissives, behabitives and expositives.

\section{Verdictives.}

This type of utterances is used to give a verdict, estimate, grade, or appraisal. Here, the speaker makes an assessment or judgment about the act of the addressee. Thus, the teacher used verdictives when giving feedback. As Austin stated giving feedback is just not a function of saying something because it indicates an unmarked use by acting. In verdictives, actions can be viewed both positively and negatively by congratulating, praising, and on the other hand, by criticizing or blaming. For examples,

\section{T: You are correct.}

Very good

\section{Exercitives}

The teacher used exercitives to express power, rights, or influences as in appointing, ordering, warning or advising. This highlights a speech act in which a decision is made regarding action. This can be commonly found in teacher talk when giving commands, advice, or instructions. It is because the teacher is the one who holds the authority in the class. Here, the exercitives that the teacher used in her language are,

\section{T: Don't use the correction pen just cut the answers and} write it.

\section{Commissives.}

It is used to promise or undertake or commit one to do something. As Austin cited the use of this type of speech act is not only to utter a statement but also to perform an act. In that case, the teacher used commissives to encourage and support the student to do an activity. It can be exemplified as the following,

T: Don't worry about the meaning. You don't need to know all this meanings of these words just try to find the answer.

\section{Behabitives.}

The teacher used behabitives in the functions of apologizing, congratulating, blessing, cursing or challenging. The use of behabitives as speech acts implies the expressions of attitudes towards the conduct, fortunes or attitudes of others. According to the present study, the teacher uses behabitives as following examples,

\section{$\mathrm{T}$ : What is the answer? \\ S: Sailing... \\ T: Very good, you are correct. Sailing.}

\section{Expositives}

These are used to refer to how one makes utterances fit into an argument or exposition. The teacher used expositives to clarify reasons, arguments or communication during the lesson as the following;

$\mathrm{T}$ : now imagine in your imagination if you are in the ship, what will you do? Then there is a storm then there are so many sea waves, what will you do?

Thus, it is obvious that according to Austin's theory, the teacher talk in the ESL classroom of the study has used more verdictives, expositives and exercitives and fewer commissives and behabitives in her speech. Thus, each utterance has its propositions but as Austin cited, an action always has more than a function. The teacher said an utterance not just to deliver a message but all the utterances are presented by the teacher to act. Hence, as Austin's speech act theory 
every utterance of the teacher talk can be considered as speech acts.

\section{Code-switching and code-mixing in teacher talk.}

Code-switching and code-mixing can be found as the main element not only in teacher talk but also in students' language in an ESL classroom. As Grosjean (1982), Romaine (1994) stated code-switching can be discussed along the entire continuum of proficiency, and that code-switching is a typical occurrence among bilinguals in classroom contexts. As Canagarajah (1995) and Pennington (1995) mentioned code-switching and codemixing in the language classroom is obvious and unavoidable with bilingual learners. Codeswitching occurs when speakers use two languages in their speeches. It mainly occurs between utterances which are known as inter-sentential. Code-mixing also has the same occurrence but it mostly happens within a single utterance which highlights as intra- sentential. Faltis (1989) mentioned that code-switching in the classroom should follow with two guidelines. Those are,

- Only inter- sentential language mixing can be allowed in the classroom.

- All language switching should be school-professiona initiated.

According to the present study, the teacher used the codeswitching and code mixing when giving feedback, students' clarification, teacher asking vocabulary questions, seeking teacher's informing and teacher's giving commands.

Further, the researcher could observe the way that the lesson becomes comprehensible for the students when the code-mixing and code-switching are involved in teacher talk. It helped the teacher also to explain the lesson, to clarify the meaning of the difficult words and to prevent misunderstanding of the meaning of new words. In addition, the study shows how the learners also expect code-switching and code-mixing in teacher talk as it helps them to achieve a better understanding and creates a comfortable and safe environment of learning as L1 serves a supportive and facilitating role in the classroom. Further, the teacher's use of codemixing and code-switching allowed more opportunities for learners to practice their English skills.

Code-switching and code-mixing in teacher talk in the present study are,

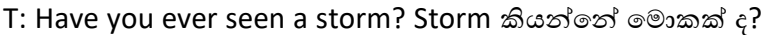
Storm? Yes, speak louder. Storm? ฉ

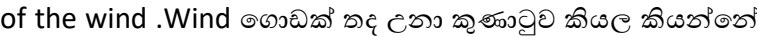

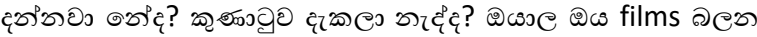

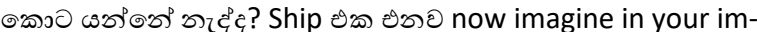
agination if you are in the ship, what will you do? Then there is a storm then there are so many sea waves, what will you

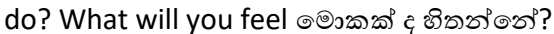

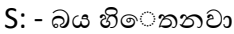

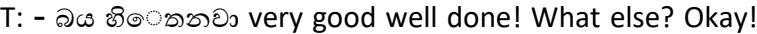

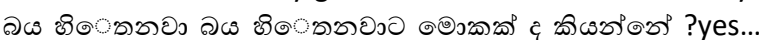
you are very good!

S: - Scared

T: - very good

\section{Power and solidarity in teacher talk.}

The researcher analyzed the teacher talk relating to the strategy of power and solidarity as another linguistic aspect of sociolinguistic theories. Here, this highlights how the teacher held power and solidarity to generate relationships with students. The findings of this case study have been used to portray a deep understanding of power and solidarity in teacher talk. As Tannen (1996) cited power and solidarity are paradoxical relations with each other. That means any show of solidarity necessarily entails power at the same time, any shoe of power entails solidarity by involving participants with each other. Further, this study emphasizes the use of code-switching in teacher talk to establish power and solidarity because the manipulation of two languages is related to the social situation in a given community is important.

First, when considering the power used in the teacher talk, it is clear that the teacher occupied the role of authority and power structured by the demands of the curriculum. It highlights through the way the teacher guided the students in the lesson, instructed, took turns at will, allocated turns to the others, determined the topics, interrupted, reallocated turns, judged to be irrelevant to those topics, and provided feedback. The examples for the use of authority and power are,

T: Okay, before that I want to do a small activity it is very easy. Why? What is your problem? Are you okay? It is very easy, you have to, okay look at this paper. Everyone look at here, there are only 10 sentences. Okay, before that I want to do a small activity it is very easy.

According to these, it emphasizes the idea that the teacher was in control of what happens in the classroom, in other words, she had the power of controlling the linguistic behavior of the students. However, the teacher also had solidarity and relationships with the students. The classroom necessarily brings the teacher and the students closer. Here, the teacher asked many questions to share the ideas of the students and to check their levels of understanding. Thus, the use of more questions in teacher talk portrayed a close relationship between the teacher and the students, it is because asking questions gives opportunities for the students to share their ideas with the teacher and it helps to build up a friendly relationship with each other. The examples in the current study are,

T:- Okay! what else? And you are frightened of the storm, you want to go to a land or you can go to an island. What is an island? Island? I can't hear Basuru speak louder. Island?

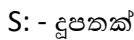

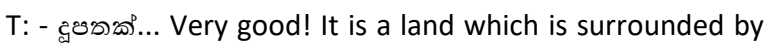

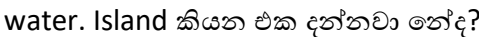

The findings of the study show how the teacher established solidarity among students with the use of code-switching. The use of the first language in teacher talk which is related to the social situation of the speech community in the class allowed the teacher to be close with the student, indicating,

T:- Who is the pilot? Who is the pirate? Pirate!

S: - Captain

$\mathrm{T}$ : - oh! Not in a plane, not a captain, pirate?

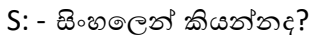

$\mathrm{T}$ : - no it is okay. If you know the word you can tell it in Sinhala. No, I am talking about a ship. Then who should be there?

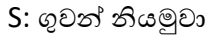

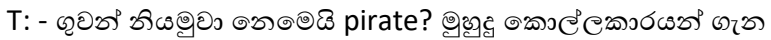

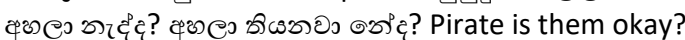

At the same time, the teacher used her language to set the mood of the class by asking about the way they spent the vacation while switching the code as following,

T: - Very good. Okay, how is your vacation? How is your vacation (in a high voice)? 
S: - Very good

$\mathrm{T}$ : - Very good, excellent what about the others?

In that case, it is explicit that the teacher established power and solidarity in her talk according to various types of functions like giving instructions, giving commands, and asking questions to achieve the objectives such as to guide the students, to control the class, and to build up a rapport.

\section{Impact of Teacher Talk on the students' learning.}

The teacher talk in an ESL classroom influences on students' learning. It is because the teacher talk is the first effect that allows the students to communicate with each other by using the target language. Here, the influence of teacher talk on learners' second language acquisition portrays in two ways. Those are,

- Fluency and accuracy

- The amount of teacher talk

Fluency and accuracy in teacher talk affect the learners' L2 acquisition. The classroom is the only place that learners can expose to the target language. Thus, their exposure can be initially begun by listening to the teacher talk and then through imitation. In that case, the teacher talk should comprise accurate, simple, and clear sentences and accurate pronunciation. As Zhou Xing and Zhou Yan (2002) stated that type of teacher talk becomes a decisive factor in classroom teaching.

Furthermore, the amount of teacher talk also can be highlighted as another significant fact which affects the learners' second language acquisition. As most of the researchers said, the teacher should reduce the frequency of teacher talk because the learners are the ones who should speak more in a language classroom to practice. Thus, time should be allocated for all the learners in the classroom to speak with each other. If the teacher avoids her talk in the classroom then it will give more chances for the students to talk. As Harmer (2000) pointed out getting students to speak to use the language they are learning is a vital part of a teacher's role. Thus, the teacher should encourage and allow the students to speak or communicate with each other. Therefore, the teacher talk should be more encouraged and supportive to provide more opportunities for students to practice the target language. Thus, it is explicit that the teacher's feedback and questions have a great influence on learners' learning. Moreover, Wong and Fillmore (2003) brought out the idea that the amount of time that the teacher should spend talking in the class is related to the learners' language proficiency.

According to this study, the teacher exerted her control over students by using her talk and she sometimes repeated the same instruction. It may be because of the level of the students. The teacher had to makes the students aware of what they were asked to do. Further, sometimes students answered the questions incorrectly but it also can be considered as a way to provide genuine communicative uses of the language. Here, another important fact is the teacher's language used to give feedback. It is effective for learners' learning than anything else. Some researchers have found that positive feedback is more effective than negative feedback to change students' motives or attitudes towards second language acquisition (Ur, 2000). In this study, the researcher found many praises that the teacher used to encourage and support learners. At the same time, it is obvious that the teacher used 'explicit correction' and 'self-repair' to correct the mistakes.
Here, it is evident that the teacher talk has a great impact on learners' second language acquisition. Further, this coveys according to the appropriateness and the accuracy of teacher talk to suit the proficiency of students.

Learners' perspectives towards Teacher Talk in second language acquisition.

To support the result of observation related to teacher talk in generating interactions in ESL classroom the researcher seek for students' opinion on their teacher talk. To fulfil the research, a questionnaire with five items were given to students in the class. According to the responses of the surveyed students, it emphasizes that Teacher Talk directly affects second language acquisition. The learners believe that their comprehensibility depends on the way the teacher uses the language in the classroom. Thereby, the medium of language becomes significant for learners to understand the target language. Thus, most of the learners prefer to learn the second language along with their first language. Moreover, the respondents indicate that if the teachers use both $L 1$ and $L 2$ in explaining the lesson, the meaning of the words, asking questions, giving feedback and instructions it becomes effective for the students' language acquisition and in generating classroom interactions in ESL classroom.

\section{CONCLUSION}

Findings and contributions: Few researchers have examined teacher talk and characteristics of classroom interaction. However, this study contributes teaching and learning English as a Second language by highlighting the effects of teacher talk in creating interactions in ESL classroom. Though this is a limited case study on the effect of ESL teacher talk in creating classroom interactions, it expounds that the use of teacher talk affects directly to create classroom interactions in ESL context as the main objective of the current paper.

The findings of this study emphasize the impact of teacher talk on the students' second language acquisition highlighting various functions of a language classroom. It portrays the idea that teacher talk plays a significant role in language teaching and learning. Further, this study proved the idea that the success of teaching depends on the way that the teacher uses her language to interact with the students. As discussed in the findings, the surveyed learners generally expect to participate in the lesson actively as they prefer to be asked questions and it indicates the learners' strong desire for participation and their higher expectation toward the opportunity of speaking.

Thereby, it emphasizes that teacher talk becomes a key factor in generating interactions in the ESL classroom. Further, the findings convey that the learners prefer when the teacher code switches from L1 to L2 or vice versa during the class as it helps the students to understand the target language well. Even the studies found that L1 should be avoided in the language classroom because of transfer yet the use of $\mathrm{L} 1$ as a facilitator for learning $\mathrm{L} 2$ helps students to gain reliance and feel a friendly atmosphere in the classroom. The researcher focused on the major functions of a teacher talk such as questioning, giving instructions and giving feedback as the major findings of the study.

At the beginning of the study, the definition of teacher talks and its use to generate the classroom interaction patterns had been discussed as the theoretical background of the study. Thus, the teacher talk used in an ESL classroom was analyzed according to the researcher's observation, the 
framework of the teacher talk, and the questionnaire given to both learners and the teacher.

Moreover, the teacher talk was further discussed according to the sociolinguistics theories as Austin's speech act theory and the use of code-switching, code-mixing. It is highlighted the idea that the teacher talk varies according to the functions of the class, stages of the lesson and the level of the students. Thus, this case study focused on how teacher talk affects classroom management and it portrays that the teacher uses the language to ask questions and to give feedback and instruction as the main functions of the teacher talk. Thereby, the present study would be beneficial for the ESL teachers to realize the value of teacher talk in creating classroom interactions in the ESL context.

Limitations and further study: The first limitation of the study can be related to the limited population of the subjects. An ESL teacher and twelve ESL students of a tuition class involved in the study is too limited. In addition, this research just covered the major functions of teacher talk and its effects in generating interactions in ESL classroom by observing one ESL classroom; thereby, the current study does not provide an overall notion on teacher talk because the use of teacher talk may vary from one teacher to another and its effects in creating interactions also may differ according to the classroom environment.

Thereby, the following aspects deserve further research,

Firstly, more case studies on a large scale are needed to carry out. Therefore, there will be more comprehensive and analytical materials on Teacher talk.

Secondly, there will be more research on other aspects of teacher talk as the amount of teacher talk and its effect on language acquisition of the learners and the ways to minimize teacher talk in case of maximizing student talk.

Thirdly, the present study will further investigate the relationship between Teacher talk and second language learning in government schools. In addition, the effects of Teacher talk on students' learning in detail still needs further research.

To conclude, the present work does some research on the effect of teacher talk in generating interactions in ESL classroom and the findings of it contribute to the investigation of English as second language teaching even some limitations exist in this study.

\section{REFERENCES}

Allwright, D., \& Bailey, K. M. (1991). Focus on the language classrooms An Introduction to classroom research for language teachers. Cambridge University Press.

Brown, G. (1983). Discourse Analysis. Cambridge: Cambridge University Press.

Brown, H. D. (2007). Teaching by Principles: An Interactive Approach to Language Pedagogy. New York: Pearson Education.

Celce-Murica, M. (1989). Interaction and Communication in the ESOL classroom. In A Forum Methodology (4).

Malamah-Thomas, A. (1987). Classroom Interaction. Oxford: Oxford University Press.

Chaudron, C. (1988). Second Language classrooms: Research on Teaching and Learning: Camberidge University Press.

Cook, V. (2000). Second Language Learning and Language Teaching. London: Edward Arnold.

Donald, K., \& Paul D. Eggen. (1989). Learning and Teaching: Research based Methods. Allyn and Bacon.

Ellis, R. (1985). Understanding Second Language Acquisition. London: Oxford University Press.

Krashen, S. D. (1989). Language Acquisition and Language Education. UK: Prentice Hall.
Larsen-Freeman, D., \& Long, M. H. (1991). Input Modification and Second Language Comprehension. An Introduction to Second Language Acquisition Research.

Malamah-Thomas, A. (1987). Classroom Interaction. Oxford: Oxford University Press.

Nunan, D. (1989). Understanding language classrooms: A guide for teacher initiated actions. Cambridge: Prentice Hall International Ltd.

Nurpahmi, S. (2017). Teacher Talk in Classroom Interaction. English, Teaching, Learning and Research Journal, 3(1), DOI: https://doi.org/10.24252/Eternal.V31.2017.A4

Richards, J., \& Lockhart, C. (1994). Reflective Teaching in Second Language Classrooms. Cambridge: Cambridge University Press.

Richards, J. (1998). The Context of Language Teaching. Cambridge: Cambridge University Press.

Ronald, W. (2006). An Introduction to Sociolinguistics. USA, Blackwell Publishing.

Sofyan, R. R. \& Mahmud, M. (2014). Teacher Talk in Classroom Interaction. Journal of English Language Teaching, 1(1), DOI: https://doi.org/10.26858/eltww.v1i1.841

Thornbury, S. (1996). Teachers research Teacher Talk. ELT Journal. 50(4), 279-89.

Ur, P. (2009). A Course in Language Teaching: Practice and Theory. UK: Cambridge University Press. https://sacunslc.files.wordpress.com/2015/03/penny-ur-a-course-in-

Walsh, S. (2011). Exploring Classroom Discourse: Language in Action. Oxford: Routlege Taylor \& Francis Group.

Yanfen, L., \& Yuqin, Z. (2010). A Study of Teacher Talk in Interactions in English Classes. Chinese Journal of Applied Linguistics, 33(2), 76-86. 
